\title{
O ANJO DO LARE FEMME FATALE: A REPRESENTAÇ̃̃̃O DA MULHER VITORIANA NA OBRA CARMILLA, DE LE FANU
}

\author{
THE ANGEL IN THE HOUSE AND FEMME FATALE: THE REPRESENTATION \\ OF VICTORIAN WOMAN IN CARMLLLA, BY LE FANU
}

\section{RESUMO}

Este trabalho analisa o discurso acerca da representação da mulher vitoriana no final do Século XIX, por meio da obra literária Carmilla: a vampira de Karnstein, de Sheridan Le Fanu, de 1872. A representação angelical e meiga, o Anjo do Lar (PATMORE, 1864), uma mulher sem desejos, totalmente reprimida sexualmente e objeto do homem, é representada pela personagem Laura. Ao passo que Carmilla representa a libertação dessa mulher, correspondendo à imagem da Femme Fatale, em sendo sedutora e dominadora, se encaixaria no padrão da Femme Fatale, rompendo com os padrões sociais deste período.

Palavras-chave: Mulher. Sexualidade. Vampiro.

\begin{abstract}
This work analyzes the discourse about representation of the Victorian woman at the end of Century XIX, through the literary work Carmilla: the vampire of Karnstein, of Sheridan Le Fanu, in 1872. Theangelicand sweet representation, the Angel in the House (PATMORE, 1864), a woman totally repressed sexually and object of man is represented by the character Laura. While Carmilla represents the liberation of this woman, corresponding to the image of the Femme Fatale, being seductive and domineering, would fit the Femme Fatale pattern breaking with the social patterns of this period.
\end{abstract}

Keywords: Woman. Sexuality. Vampire.

\section{Introdução: Autor, Obras e Carmilla}

A mulher Femme Fatale para a sociedade da era vitoriana é, sem dúvida, aquela que de alguma maneira está fora dos padrões sociais da época, ou seja, de tudo aquilo que fugisse da regra, pois era visto como subversivo e transgressor. Assim ocorre com a mulher que de alguma forma, tenta se libertar do crivo da mulher ideal, angelical, pura, que segue e aceita ser submissa à religião, ao homem e à sociedade, "[...] la femme fatale no es un ser social, es sádica y sólo depende de sí misma [...]” (PÉREZ, 2004, p. 708), logo. Carmilla é a mulher que rompe com os grilhões da moral, ela não

\section{Tatiana Souza}

Universidade Federal do Rio Grande (FURG). E-mail: taty100481@gmail.com

Sueder Souza

Universidade Tecnológica Federal do Paraná (UTFPR). E-mail: swedersouza@gmail.com 
é a mulher que vai dar continuidade à vida, ela vai viver em busca dos seus desejos, vai viver a vida que a mulher representada pelo "anjo do lar" anseia em seus pensamentos.

Carmilla é uma obra literária de ficção sobrenatural, escrita por Sheridan Le Fanu, em 1872, sendo ele considerado o pai da história fantástica. Joseph Thomas Sheridan Le Fanu (J. S. Le Fanu) nasceu em Dublin, Irlanda, em 1814, formadoem direito em Trinity College, iniciou sua trajetória literária tradicional aos 14 anos. Interessavase por vampiros, fantasmas e personagens sobrenaturais, utilizava a imagem gótica, ambientes sombrios, castelos afastados do meio urbano, etc., além disso, suas obras eram opostas aos padrões e a moral do período vitoriano. Graduado em Direito, largou a carreira para dedicar-se ao jornalismo, colaborador ativo da revista Dublin University Magazine, na qual publicou seus contos e novelas. Além de ser considerado o pai da literatura fantástica, ele tornou-se um dos escritores mais populares do século XIX.

As obras de Le Fanu estão caracterizadas em três períodos. O primeiro: entre 1838 e 1848, dedicou-se a escrita de baladas, canções, como: "Adventures of Sir Robert Ardagh" e "The Ghost and the Bone-Setter". O segundo: entre 1848 e 1858, dedicandose a carreira jornalística publicando diversos contos e novelas no jornal do qual, posteriormente, em1861, seria proprietário.

Terceiro e último período: entristecido pela morte de sua esposa em 1858, Le Fanu passou a ficar recluso em sua casa, distante do convívio social. Dedicou seu tempo à escrita literária, o que pode ter contribuído para sua inspiração, influenciando a escrita com detalhes negativos e obscuros em suas obras, que são: Uncle Silas (1864), Guy Deverell (1865), e a coleção de contos In a Glass Darkly (1872), esta última teve grande expressividade, sendo classificada pelos críticos da época como a melhor no que tange o estilo gótico vitoriano, além de contos como: Green Tea, The Room in the Dragon Volant, The Familiar. A obra de maior repercussão em sua trajetória literária foi Carmilla considerada uma obra vampírica inovadora e formadora do mito do vampiro na literatura inglesa.

Anterior a Carmilla, existiram outras obras que versavam sobre a temática vampiresca feminina. Primeira, Christabel, de Samuel Taylor Coleridge, em 1797, e a segunda, o conto The Vampire, de John Polidori, em 1819, porém Carmilla é a primeira obra em que o mito do vampiro é representado pela figura feminina.

A obra Carmilla é narrada pela personagem Laura, onde narra todos os detalhes e sentimentos dessa relação de "vida e morte" entre Carmilla a própria personagem narradora. A trama tem como ambiente um castelo na encosta da colina, numa floresta na Estíria, na Áustria, um lugar isolado e primitivo, característico de uma literatura fantástica no estilo gótico.

Sendo assim, Francisco Javier Sánchez-Verdejo Pérez (2004, p. 398) discorre:

Hoyendía la noción de género gótico sugiere un inmediato referente: un tipo de literatura que gira en torno a lo macabro, lo misterioso, lo fantástico, lo que va más allá de larazón lógica; y este tipo de literatura se desarrollócon bastante profusión en los siglos XVIII y XIX. 
Conforme a citação acima, a literatura gótica está ligada àquilo que remete ao mistério, e que aguça o medo dos leitores. O termo gótico possui vários significados e características o que acaba dificultando a classificação de uma obra neste estilo, “[...] El término inglés gothic- proveniente de la palabra latina gothicus- puede referirse a conceptos muy diferentes en campos muy variados [...]" (PÉREZ, 2004, p. 398), justificando este problema decorrente das suas formas diferentes de conceituar e analisar esse estilo, o autor apresenta os fatos que contribuíram para conceituação do estilo gótico literário, que são:

Determinados pueblos germánicos provenientes de las orillas bálticas que invadieron Europa a partir del siglo III (sentido original que tenía en latín) llegando hasta la Península Ibérica y siendolos debilitadores de lImperio Romano.- Todo lo medieval enoposición al período clásico anterior y renacentista posterior.Un movimiento artístico que aparece en la Europa de los siglos XII y XIII. Una nueva tendencia arquitectónica que tuvo lugar en las últimas décadas del siglo XVII, llamado gothicrevival. Relacionado conel significado que analizamos aquí, un tipo de literatura de esa época que pronto se conoció como gothic romance (PÉREZ, 2004, p. 398-399).

Conforme a citação acima, o estilo gótico começa a adquirir suas características a partir desses fatos, sendo que muitas delas tiveram conotação negativa, isto é, o gótico vem de "godo" que remete às tribos germânicas, responsável pela queda do império romano e ascensão do medievo. Além disso, o termo gótico surgiu no Renascimento, como um insulto estilístico, já que o período medieval remete às trevas, visto como bárbaro eatrasado, ao passo que o góticoédepreciativo. Portanto, a partir dessas discussões o termo gótico passou a ser associado ao estético e artístico, como discorre Pérez.

Por tanto em el campo de la literatura, el adjetivo gótico se comenzó a emplear por una asociación con su uso en el ámbito de lo estético y artístico: los textos conocidos como góticos se suelen desarrollaren castillos siniestros, abadías en ruinas, criptas, catedrales... de manera que la identificación con el término arquitectónico es muy obvia y directa (PÉREZ, 2004, p. 401).

Na citação acima, o autor apresenta como a literatura gótica iniciou suas características, locais onde a trama dos textos, livros, novelas góticas são ambientadas. No caso, locais como cemitérios, templos, castelos, ambientes catastróficos são evidentes nessas obras. O gótico, surge, então, dentro da literatura romântica, rompendo com o pensamento científico, essas obras têm como fundamento o sobrenatural e a espiritualidade é opositora do pensamento iluminista, que é racional.

A primeira obra romântica em estilo gótico foi escrita por Horace Walpole em 1764, “The Castle of Otranto”. Na sua primeira edição o autor preferiu o anonimato 
usando um pseudônimo. Haja vista, que este era o século da razão e sua obra era algo que fugia ao racional, com certeza é algo extremamente arriscado e perigoso para a época. Essa obra apresenta em seu enredo uma relação entre o popular, sangue e paixão, “[...] es una historia donde se mezclalo popular, la sangre y la pasión, junto conun fantasma monstruoso, todo ello ambientado en el siglo XIII [...]" (PÉREZ, 2004, p. 460), portanto, esta obra apresenta características do gótico, seja pelo o ambiente, a relação com o sobrenatural, presença de uma jovem frágil virgem, desaparecimentos misteriosos e, acima de tudo, a presença do tirano.

Conforme Pérez:

En The Castle of Otranto están ya presentes todos los elementos del género de novela gótica: ruinas, una doncella virginal perseguida por unos laberintos subterráneos, criptas, desapariciones misteriosas, presencias sobrenaturales, unhéro e tiránico, situaciones sobrenaturales, la historia ubicada en una sociedad medieval (PÉREZ, 2004, p. 460-461).

Como podemos observar na citação acima, a obra The Castle of Otranto é uma obra precursora do estilo gótico, da qual aparenta ter influenciado obras posteriores, carregando suas características góticas. Outra característica está ligada aos pensamentos mundanos dos personagens, suas mentes são envolvidas por pensamentos que rompem com os preceitos da religião e do divino, “[...]En la historia de Walpole, como en la mayoría de las novelas góticas, los personajes tien en pensamientos pecaminosos, y, por tanto, deben ser castigados por un poder divino [...]" (PÉREZ, 2004, p. 461), desta forma, os subversivos devem ser castigados sob a lei divina.

Assim como Sheridan, Le Fanu utilizou suas obras como uma forma de expressar sua opinião e criticar a sociedade vigente; Walpole fez o mesmo criticando a política e a sociedade em geral através de The Castle of Otranto.

Para Pérez (2004, p. 46):

La introducción de Walpole a su obra es una especie de manifiesto literario que aboga por la creación de un nuevo tipo de escritura. Su proyecto implica tanto um rechazo del racionalismo volteriano como de los excesos de fantasía que habían minado lavero similitud de la ficción: su nuevo tipo de novela propone que los personajes actúe ne siempre como se supone que actuarían hombres y mujeres en circunstancias extraordinárias.

Conforme o autor da citação acima, a obra de Walpole surge como uma revolução no campo das letras, em um período idílico e nostálgico, “[...] El entusiasmo del público británico por lo sobrenatural y lo macabro no es nuevo: se trata de un género de tradición nacional que se remonta a los orígenes del país [...]" (PÉREZ, 
2010, p. 424), a preocupação é em manter ativa a tradição em uma sociedade que está totalmente ligada diretamente às questões materiais.

A literatura gótica, além das características relacionadas ao ambiente e seres sobrenaturais, apresenta outras que desafiam a fé cristã e a sanidade, o bom ligado ao maligno, sangue, dor, morte, crueldade, estão presentes nessa literatura. Tudo muito aterrorizante, obscuro, carregado de muito suspense.

\section{O Contexto do Período Vitoriano}

O período vitoriano (1837-1901) foi assim conhecido por ter sido governado pela Rainha Vitória durante sessenta e quatro anos. A Rainha Vitória, foi criada nos moldes da mulher virtuosa, do lar, isto é, desde a infância foi retirada do convívio social, instruída pela Igreja e pelas preceptoras, sem contato com a figura masculina e, quando havia, sempre estava acompanhada de alguém.

Laura foi criada seguindo os padrões sociais e de conduta desse período, haja vista, que seu castelo é afastado dos centros urbanos e vilarejo. Ela menciona: "Nada pode ser mais pitoresco e isolado. A propriedade fica na encosta de uma colina, numa floresta" (LE FANU, 2010, p. 39). Como podemos observar o local era bem afastado, tinha pouco contato com outras pessoas, às vezes recebia visitas, a maioria meninas jovens como ela, outras ela visitava. Solitária, fora do convívio social, regulada e instruída pela sua preceptora.

A mãe da Rainha Vitória, a Duquesa de Clarence, dedicou-se fervorosamente para que a Rainha Victoria fosse "[...] uma rainha cristã. Ela dedicou todas as suas energias a essa tarefa; e, à medida que a criança crescia. A duquesa se orgulhava de constatar que seus esforços tinham sido bem-sucedidos[...]" (STRACHEY, 2015, p. 49). Desta forma, concordando com a citação, vemos que a presença da moral cristã estava enraizada neste período, e que, a Rainha Vitória foi forjada nesse modelo social.

Quando Laura tinha aproximadamente seis anos, ocorreu o primeiro contato sobrenatural com Carmilla, aterrorizada, ela entrou em pânico, no dia seguinte recebeu a visita de um padre, que rezou e fez uma oração junto à Laura:

Lembro-me que mais tarde, naquele mesmo dia um senhor de aspecto nobre, trajando batina preta, entrou no quarto acompanhado da babá e da arrumadeira, e se dirigiu, primeiramente, às duas, e depois conversou comigo com amabilidade. Tinha a fisionomia meiga e gentil, e me disse que todos rezariam, [...]" (LE FANU, 2010, p. 44).

Percebemos que na religião, a fé está presente desde a tenra idade. Em outros momentos, ela começa a questionar sobre a religiosidade da Carmilla, "[...] Muitas vezes me perguntava se a nossa bela hóspede costumava rezar. Eu nunca tinha visto 
Carmilla de joelhos. [...]" (LE FANU, 2010, p. 87). Percebe-se a relação intrínseca que as mulheres tinham com a religião.

Remontando à Rainha Vitória, que tomou posse do trono em 1837, sua corte era considerada modelo, não só pela integridade do reinado, pois era um governo que não tinha nenhum escândalo que pudesse colocar em xeque a moral deste reinado.

Para Giles Lytton Strachey (2015, p. 163):

Ela era mais - era a encarnação, o ápice vivo de uma nova era da humanidade. O último vestígio do século XVIII tinha desaparecido; as sutilezas e o cinismo tinham sido reduzidos a pó; e o dever, o trabalho, a moralidade e a vida doméstica triunfaram sobre eles.

De acordo com a citação acima, podemos ver o momento que a Era Vitoriana atinge seu ápice na história. Além disso, esse período é considerado o auge da Revolução Industrial, ocorrendo uma renovação tecnológica.

Para Francisco Javier Sánchez-Verdejo Pérez:

En la mente de muchos, la reina Victoria personificaba el espíritu de la Inglaterra del siglo diecinueve: ella era la reina del Reino Unido, Gran Bretaña e Irlanda así como la emperatriz de la India. Era también la madre de nueve hijos. Su monarquia era un modelo de respetabilidad, autodisciplina, conservadurismo y virtudes domésticas. El poder mundial de Inglaterra se expandió debido al papel tan crítico que la reina desempeñó al comienzo de siglo; la convirtió em el primer estado moderno industrial (PÉREZ, 2011, p. 512).

A imagem da Rainha Vitória e de sua corte servia de modelo nas vidas das pessoas, Sheridan Le Fanu, apresenta na sua obra sucintamente sobre essa devoção, "[...] meu pai e eu falamos inglês, idioma que praticamos diariamente, para não o esquecer e também por razões patrióticas. [...]” (LE FANU, 2010, p. 41), portanto percebe-se o valor que o governo inglês tinha para esses atores sociais. Além disso, a era vitoriana foi um período de transições sociais e econômicas e, também, no que tange as mudanças com relação a modernizações da indústria. Uma nova Revolução Industrial estava se originando, era um período de prosperidade.

De acordo com Hobsbawn:

Para o século XIX, a principal inovação consistia na atualização da primeira revolução industrial, através do aperfeiçoamento da tecnologia do vapor e ferro: o aço e as turbinas. As indústrias tecnologicamente revolucionarias, baseadas na eletricidade, na química e no motor de combustão, começaram certamente a ter um papel de destaque, em particular nas novas economias dinâmicas. (HOBSBAWN, 1988, p. 81). 
Dentro deste contexto, e com o advento da prosperidade econômica que ocorrera pelo avanço tecnológico industrial, faz-se emergir uma nova classe social, a burguesia. Sobre esse emergente estilo social, Campos (2008) nos diz:

A era vitoriana teve marcos importantes para a história social, pois é considerada o auge da revolução industrial inglesa e do império britânico. Naquele momento, a sociedade tomada pelo ideal burguês vivia à sombra da superficialidade, falsidade e preconceito cujo domínio permitia a poucos o controle econômico e aos homens, chefes de família, o total domínio social. O período vitoriano, dessa forma, permitiu certo cultivo à inocência e a sociedade passou a idealizar a inocência e, com isso, evitar situações e sentimentos desagradáveis pertencentes ao mundo real era meta para a educação dos jovens, ainda mais no que concerne ao mundo feminino. (CAMPOS, 2008, p. 64).

Concordando com a citação acima, o avanço do capitalismo fez com que a sociedade patriarcal, do contexto aqui levantado, seenraizasseainda mais, assegurando a perpetuação do masculino sobre a tutela da sociedade e da figura feminina, assim, “[...], la era Victoria foi un momento de prosperidade así como de estrictas normas morales [...]" (PÉREZ, 2011, p. 514).

\section{A Representação do Anjo do Lar}

Assim, a partir da Revolução Industrial, a sociedade vitoriana começou a sofrer transições no que se refere ao público e ao privado - lembrando que outros discursos transversais, como os médicos, legislativos, leis de divórcio e de propriedade etc., corroboraram para o lugar de atuação das mulheres aos confins do privado - e como forma de controle, usou a moral. Por isso, a era vitoriana ficou conhecida como uma sociedade moralizadora, coube a ela buscar um equilíbrio entre o público e o privado, e esse ponto foi o lar.

O contexto social da era vitoriana inspirou Sheridan Le Fanu na construção de Carmilla. Nesta obra ele apresenta a imagem da mulher vitoriana, caracterizada por Laura, representando o anjo do lar, que segue a sociedade conservadora e aceita a submissão da sua feminilidade, agindo dentro da naturalidade que lhe foi imposta, quando Laura narra seu cotidiano no castelo: “[...] Minhas preceptoras exerciam sobre mim o controle que seria de se esperar de damas sábias, [...], (LE FANU, 2010, p. 41).

Esta passagem demostra o rigor na educação das meninas, normalmente, as preceptoras tinham o domínio de outras línguas e conhecimento em diversas áreas, tornando-as aptas nas instruções de futuras esposas e damas. A mulher representada pela pureza angelical, delicada, frágil, assexuada que antes era tutelada ao pai agora é 
pelo marido, esta é a representação da mulher vitoriana, o anjo do lar, aquela que foi criada para ser submissa ao homem e à sociedade conservadora.

Segundo Perrot (2005), “[...] as mulheres se enraízam na natureza; elas têm o coração, a sensibilidade, a fraqueza também. A sombra da casa lhes pertence. [...]" (PERROT, 2005, p. 269). O homem afirma a inferioridade da mulher através do biológico, sempre a colocando de forma reduzida, oprimindo tudo aquilo que vinha ou se referia ao sexo feminino.

A condição biológica da mulher lhe coloca em posição de submissão diante do sexo oposto, da sociedade e da igreja, sendo desses três seus carrascos, vigiada, punida, oprimida, silenciada de todas as suas ações. A mulher vitoriana está encarcerada em seu próprio corpo. Antoine Léonard Thomas em seu livro O que é uma Mulher? Um debate prefaciado por Elisabeth Badinter, nos diz: "[...] A natureza nos põe à prova com dor, as leis com a opressão, e a virtude com os combates [...]" (THOMAS, 1991, p. 39). Portanto, a mulher sempre está aquém de alguém, sempre terá alguém que a faça lembrar a sua posição diante do público e do privado.

A religião responsável pelas leis morais exerceu poder sobre as mulheres e a sociedade em geral, além disso, ela deu poder a essa mulher, isto é, "Entre as religiões e as mulheres, as relações têm sido, sempre e em toda parte, ambivalentes e paradoxais. Isso porque as religiões são, ao mesmo tempo, poder sobre as mulheres e poder das mulheres" (PERROT, 2016, p. 83).

Para Perrot (2016), a religião tinha uma relação de duplicidade, onde a mulher se colocava tanto como mulher virtuosa quanto como mulher profana; ao mesmo tempo em que ela servia a sua religião atraindo para seu interior seu marido e filhos, mantendo a moral e a virtude em seu lar, caso ela subvertesse os preceitos impostos pela igreja, seria excomungada, rechaçada, exposta diante da sociedade. Assim, a religiosidade inferiorizou a mulher a partir do seu órgão sexual, transformando, “[...] essa diferença dos sexos e da desigualdade de valor entre eles um de seus fundamentos. A hierarquia do masculino e do feminino lhes parece da ordem de uma natureza criada por Deus [...]" (PERROT, 2016, p. 83). Nesse sentido, a religiosidade parece contribuir para uma imagem negativa da mulher.

A igreja se afirmou no mito da criação, onde a mulher foi criada após o homem e originada a partir da costela do mesmo, o que a coloca como inferior a este homem, além disso, a igreja ignora a primeira versão do mito da criação, onde o homem e a mulher teriam sido criados ao mesmo tempo. Legitimando a segunda versão, ela acaba incutindo na sociedade que a mulher é inferior ao homem e sua origem vem dele, portanto, deve se submeter à dominação masculina.

Diante do crivo da sociedade, do sexo masculino e da igreja, a mulher torna-se uma presa diante do seu predador, o que acaba por colocá-la como selvagem, sendo ela fêmea e ele o macho, para tanto, disse Beauvoir (1970, p. 25): "[...] Na boca do homem o epíteto "fêmea" soa como um insulto; no entanto, ele não se envergonha da sua animalidade, sente-se, ao contrário, orgulhoso se dizem dele "É um macho!".

Segundo a citação, a mulher encontra-se, neste caso, enclausurada ao seu sexo, à sua biologia, à sua natureza e isso causa desconforto ao homem, que ignora e 
sufoca a imagem selvagem da mulher, enquanto ele afirma-se diante da mulher e da sociedade como superior, capaz de dominar a sua presa. O casamento das mulheres é uma imposição social, sendo assim, obrigada a desposar-se quando a idade adulta chega, ou quando seu corpo estiver preparado. No século XIX, as mulheres eram preparadas para o casamento, a elas eram ensinadas as atividades domésticas como: lavar, cozinhar, passar, costurar, etc. Ensinada a ver seu marido, seu pai e seus filhos como prioridades, estes cabiam a ela toda responsabilidade pelo bem-estar e harmonia familiar.

Na maioria das vezes o contrato do casamento não estava acompanhado pelo carinho e amor pelo seu futuro companheiro, em suma, era um desconhecido para ela. O pretendente era escolhido sob o olhar rigoroso do pai, na classe burguesa, a posse do futuro marido era de grande relevância e, também, existia uma política familiar unindo famílias de posses para manter a ordem econômica familiar. No caso das camponesas, moradoras rurais, muitas vezes suas terras eram para subsistência, pais sem posses, largada ao seu próprio destino. Os pais também estimulavam e engendravam casamentos para livrar-se do fardo de ter uma menina, embora auxiliasse nas atividades da propriedade, sua presença era motivo de perigo, pois essas meninas poderiam ser vítimas de estupros individual ou até mesmo coletivo.

Perrot (2016, p. 45) afirma: "Preservar, proteger, a virgindade da jovem solteira é uma obsessão familiar e social”, portanto para evitar o mal e uma gravidez indesejada os pais a incentivavam o casamento ou mantinham suas filhas sob vigia e afastadas do contato social. Os estupros, além de violar a intimidade da mulher de forma brutal, mancham a sua imagem imaculada de virgem, o que acabava impedindo o seu casamento. Ela, mesmo sendo vítima, era acusada de ter se insinuado permitindo o ato.

O sexo feminino é atrelado a obrigações diante dos olhos masculinos. Após o casamento essa mulher sofre abruptamente o rompimento com sua família e infância para se juntar ao homem, dominador, ao qual será o seu esposo, tutor, carrasco, pai dos seus filhos. Diante desse fato, agora a mulher é cobrada pela maternidade, sim, uma mulher casada deve dar frutos para este homem, é uma imposição, já que ela é vista como uma procriadora, logo, "[...] como função materna é um pilar da sociedade e da força dos Estados, torna-se um fato social [...]” (PERROT, 2016, p. 69), ser mãe é uma necessidade social.

A mulher perfeita, anjo do lar, não deve opor-se a esse designo de Deus, a ela foi dada a dádiva da maternidade. Para Simone de Beauvoir: "É pela maternidade que a mulher realiza integralmente seu destino fisiológico, é a maternidade a evocação "natural", porquanto todo seu organismo se acha voltado para perpetuação da espécie" (BEAUVOIR,1967, p. 248) Desta forma, o fato da mulher estar grávida a torna "fêmea", que causará repulsa no homem, sim, neste momento ela assume seu poder fisiológico e natural, que é gerar em seu ventre outra vida, passando a ser aquilo que a natureza lhe impôs, perpetuar a sua espécie.

A gravidez para mulheres casadas e, também, solteiras, na maioria das vezes é infortúnio. A mulher casada se sente estafada por consecutivas gravidezes, neste período não existia contraceptivo. Para evitar a gravidez, ela fazia lavagens e coito 
interrompido, o segundo dependia da boa vontade do esposo, “[...] o homem irrita-se com ter de vigiar seu prazer; a mulher detesta a tarefa da lavagem; ele se ressente com a fecundidade do ventre da mulher; ela receia esses germes de vida que ele arrisca depositar nela. [...]" (BEAUVOIR, 1967, p. 248), portanto, a gravidez se tornava um fardo e as formas de prevenir causavam desconforto em ambos; o marido preocupava-se com sua satisfação sexual, enquanto ela, com mais uma vida que ela permitiria ou não nascer.

Por conta disso, muitas mulheres, a maioria casadas, morriam por complicação em abortos mal feitos, clandestinamente e, além disso, contínuas gravidezes lhe causavam a morte ou doenças. Oaborto "[...] éum fenômeno tão expandidoque cumpre considerá-lo como um dos riscos normalmente implicados na condição feminina. [...]" (BEAUVOIR, 1967, p. 249). Conforme a citação, o aborto era algo normal, apesar de ser condenado pela igreja e pela sociedade. Mesmo a mulher burguesa, que detinha de um alto poder aquisitivo, era comum isso acontecer, entre as mulheres não abastadas era prática entre elas, pois um filho era um fardo, mais uma boca para alimentar.

A era vitoriana foi um período em que a mulher, esposa, anjo do lar era a imagem deste status, através da sua imagem, da sua boa postura, da sua melhor vestimenta, ela expressava a condição financeira do seu marido. Portanto, ela deveria estar à altura daquela sociedade que tinha como exemplo a corte.

Preocupada com a etiqueta, a finesse, ela andava pelos salões da alta sociedade expondo a riqueza de seu esposo. É neste período que surge a preocupação com a aparência, ocorrendo a imposição da beleza da mulher. Conforme Perrot (2009, p. 417):

Alguns traços principais o caracterizam: para começar é um claríssimo dimorfismo sexual que resulta em salientar a diferenciação dos papéis. A mulher tem o monopólio de perfume, da pintura, da cor, da sedosidade, da renda e sobretudo de uma torturante bodysculpture que a coloca desde o início acima de qualquer suspeita de trabalho.

Perrot afirma na citação acima, sobre a preocupação com a aparência, os cuidados com o corpo e o uso de espartilhos, para afinar e contornar o corpo, a maquiagem, além de outros artifícios como: incríveis penteados, o uso de chapéus estonteantes e glamorosos, véus, luvas, etc. O espartilho usado esteticamente, lhe causava transtornos físicos e graves danos à saúde, mulheres tinham costelas e fígado afetados pelo uso contínuo deste artifício de beleza feminina, porém, ele era uma forma de dominação masculina, isto é, ele travava os movimentos das mulheres, esta perdia sua mobilidade, seus movimentos ficavam limitados.

De acordo com Mary Del Priore (2001, p. 12):

Conservando intacto o princípio aristocrático de que o corpo não deve demonstrar qualquer sinal ou marca de trabalho físico, o cânone burguês de beleza feminina perenizava as cinturas de vespa, as extremidades pequenas e finas, as peles de pêssego. 
A imagem da mulher é tudo na era vitoriana, sua aparência é aquilo que a sociedade vai, primeiramente, ter dela. Se sua aparência é impecável, expressa cuidados, sua postura ereta e confiante, essa será a imagem de uma mulher bela, virtuosa, cuidadosa, zelosa com seu esposo, pois é para ele e por conta dele que a mulher se submete a tantos cuidados e sacrifícios. "[...] Primeiro mandamento das mulheres: a beleza. 'Seja bela e cale-se' [...]” (PERROT, 2016, p. 50), esta é a verdadeira imagem da mulher, a mulher que serve de objeto, ostentação masculina, e mais nada.

A relação entre o homem e a mulher vai além dos seus órgãos genitais, essa diferença biológica afeta ambos, porém quem mais sofre é a mulher. Desde sua origem nos preceitos da religião, que nada mais é do que uma instituição que zelava para que a mulher não desviasse do seu caminho, caminho este traçado pela religião, sociedade e o homem, e cada um com a sua forma exerciam o domínio sobre a mulher. Esta mulher, submissa, dominada, domesticada aos olhos do homem e para o homem.

Conforme Beauvoir (1970, p. 232):

O homem conseguiu escravizar a mulher, mas desse modo despojou-a do que lhe tornava a posse desejável. Integrada a família e na sociedade, a magia da mulher dissipa-se em vez de transfigurar; reduzida à condição de serva, ela não é mais a presa indomada em que se encarnavam todos os tesouros da natureza.

A mulher é a escrava do homem, ele se glorifica de tê-la assim. Mesmo vendo-a como uma serva. A liberdade da mulher é um perigo para o homem, afronta masculinidade e a dominação que ele tem sobre ela. A mulher para o homem, "[...] é noite, a desordem, a imanência. [...]" (BEAUVOIR, 1970, p. 243).A mulher ao mesmo tempo em queévista como virtuosa, um anjo, ela é vista como algo negativo, que causa a desordem social, profano. É por conta dessa dualidade que o homem tem medo dela. Perrotaponta: "E todos os tempos, os homens tiveram medo das mulheres. A mulher é a Outra, a estrangeira, a sombra, a noite, a armadilha, a inimiga". (PERROT, 2005, p. 265). A mulher causa estranhamento, desde suas condições biológicas, seu físico, seu modo de enxergar o mundo, ele a oprime, limita a liberdade do seu próprio corpo, pelo fato de domá-la.

Como forma de evitar que sua natureza se rebele e se liberte o homem a confina dentro do lar, enaltecendo sua virtude para que essa não se corrompa, tendo a religião e a sociedade como cúmplice, portanto, ao mesmo tempo em que exalta a mulher, ele impõe seu devido lugar na sociedade. Haja vista, quando ele exalta a mulher, inconscientemente ela torna-se sua cúmplice.

\section{Femme Fatale}

Laura começa contando desde o primeiro contato com Carmilla, que foi na infância, quando tinha aproximadamente seis anos. Em uma noite, enquanto dormia, 
acordou sentindo estranha presença de alguém no seu quarto. Geralmente sempre tinha uma acompanhante, a sua babá, porém naquele momento ela estava só. Naquela noite ela viu uma jovem mulher em seu quarto e logo em seguida a presença ao seu lado, sentiu medo e uma terrível dor em seu peito como se alguém tivesse a mordido, Laura relata:

A jovem me acariciou, deitou-se ao meu lado e puxou-me para perto dela, sorrindo; acalmei-me deliciosa e prontamente, e voltei a dormir. Acordei com a sensação de que duas agulhas haviam sido enfiadas em meu peito, ao mesmo tempo, e dei um grito (LE FANU, 2010, p. 42).

Carmilla é uma vampira e continua sedenta de sangue e perambula entre os vivos e os mortos, seduzindo e matando suas vítimas. Laura e Carmilla se reencontrariam novamente e mais uma vez Laura seria sua vítima. Para Ludmila Rode de Campos (2008, p. 45): “[...] Em suma, o vampiro é um ser sobrenatural que vive da vida dos outros e, por isso, é um ser dependente de suas vítimas. [...]”.

O vampiro tem relação de dependência com sua vítima, sua permanência entre o mundo dos mortos vivos está na morte das suas vítimas. Essa relação de dependência não é apenas no que tange sua sobrevivência, pois a imagem do vampiro na literatura também está ligada à sexualidade, o ato de morder a vítima é um ato sexual para um vampiro. Segundo Dante Luiz de Lima (2016, p. 279): [...] O sexo no mundo vampírico é bastante sui generis, pois os vampiros tradicionais não têm relações sexuais como os seres humanos normais, isto é, eles não usam seus órgãos genitais. Assim sendo, a penetração dos dentes na sua vítima se configura em um ato sexual sem estar ligado aos órgãos sexuais como na relação humana. Então, quando essa ação ocorre não está apenas se alimentando, está aliviando seu desejo sexual.

Carmilla chega à vida de Laura pela segunda e última vez, surge a partir de um acontecimento assustador, isto é, a carruagem de Carmilla sofre um acidente próximo ao castelo de Laura, acompanhada de uma mulher que se apresenta como mãe dela e outra que não se apresenta e, somente madame Perrodon havia percebido sua presença, descreve Laura:

Mademoiselle, então, descreveu uma mulher negra, de aspecto assustador, portando uma espécie de turbante colorido, observando o tempo todo da janela da carruagem, sacudindo a cabeça e rindo e zombando da situação, com um olhar brilhante e arregalado, e os dentes cerrados (LE FANU, 2010, p. 57).

Portanto, a chegada de Carmilla e as pessoas que a acompanhavam nesta viagem, causaram certo estranhamento e desconfiança. Mesmo assim ela foi recebida, já que Carmilla ficou debilitada, impossibilitando a continuidade da viagem que seria de extrema importância para sua mãe. Laura pede a seu pai que hospede Carmilla, já que seria impossível ela viajar naquele estado e o próximo vilarejo não teria hospedaria. 
Seu pai zeloso e preocupado com a solidão da filha e pela falta de uma amiga que havia recentemente falecido e que a visitaria se não houvesse perdido sua vida, permitiu a hospedagem de Carmilla. Então em súplica pela alegria da filha, pedindo a mãe da jovem Carmilla para que a deixasse sobre seus cuidados,: "[...] Se a senhora confiar esta jovem aos nossos cuidados, este gesto propiciará a minha filha o melhor dos alentos. [...]." (LE FANU, 2010, p. 52). A partir da presença de Carmilla na casa, Laura sente-se muito feliz com a nova hóspede, passando a manter uma relação de amizade com a vampira.

A jovem Laura descreve minuciosamente a beleza de Carmilla, demonstrando encantamento. A astúcia de um vampiro é encantar as pessoas, ela se utiliza da beleza, da educação e da imagem meiga e doce que ela transmite, através do olhar envolve suas vítimas de tal maneira, como se as hipnotizassem. Para Campos (20o8, p. 45-46):

Esse fato explica as várias estratégias utilizadas para dominar: seja pela sedução, seja pela força física o vampiro atrai e é atraído, e estabelece com sua vítima uma relação de dependência que os liga eternamente. Eternamente, ou até o momento em que a vítima também passa à condição de vampiro, e daí em diante é ela que estabelecerá esse vínculo de dependência, porém com outros seres vivos.

Esse encantamento na maioria das vezes não permite que a vítima veja a verdadeira face do seu vilão, neste caso a beleza de Carmilla oculta seu vampirismo. Mesmo com toda felicidade pela presença da nova amiga, o tempo mostra alguns hábitos de Carmilla e começa a causar questionamentos e desconfiança em Laura.

Para que Carmilla ficasse hospedada na casa de Laura a mãe dela fez um pedido ao pai de Laura, que era não fazer nenhuma pergunta sobre suas origens, de onde vinha, qual era a sua família. Isso aguçou a curiosidade de todos, incluindo Laura, que em alguns momentos a questiona, porém Carmilla sempre se esquivava, discorre Laura. : "[...] recusava a revelar o nome da família, o brasão, o nome da propriedade em que residiam, e até o nome do país que habitavam [...]" (LE FANU, 2010, p. 66). Carmilla só pedia a confiança de Laura, mas ao mesmo tempo Laura se questionava por que Carmilla não confiava nela.

Em alguns momentos Carmilla insinua seu desejo para com Laura, situações que causavam desconforto e estranhamento, relata Laura:

Devo dizer que aqueles abraços ridículos, que não ocorriam com muita frequência, eu ansiava por me livrar; mas minha energia parecia se esvair. As palavras por ela murmuradas soavam em meu ouvido como uma cantiga de ninar, e entorpeciam a minha resistência, levando-me a um estado de transe, do que eu só me recuperava quando ela baixava os braços. (LE FANU, 2010, p. 67) 
Laura é criada dentro dos padrões conservadores da era vitoriana, ao passo que essas atitudes causam aversão, mesmo assim, diante desta situação, Laura acaba ao mesmo tempo demonstrando agrado pela ação, uma mistura de sentimentos surge causando perturbações. Relata Laura: “[...] Parecia um ardor de amante; sentia-me encabulada; aquilo era, ao mesmo tempo, detestável e irresistível [...]” (LE FANU, 2010, p. 68). Carmilla é uma vampira homossexual, ela sente atração por suas vítimas. Conforme Lima (2016, p. 283):

As igrejas cristãs sempre condenaram a homossexualidade, isto faz do vampiro uma criatura muito mais maligna ainda, pois ele não apenas se alimenta de sangue, mas seduz mulheres e homens, sendo assim o monstro afronta um dos valores morais mais fortemente arraigados nos dogmas religiosos, a heterossexualidade.

Portanto, Carmilla é uma transgressora, afronta os valores morais e religiosos desse período, como vampira ela se permite desejar e envolver-se com o mesmo sexo. Por isso que no decorrer da novela, vemos relatos de outras mortes de moças, na mesma faixa etária de Laura e Carmilla. No primeiro capítulo, Laura está abalada pela morte de uma amiga, filha de um general muito amigo de seu pai, que por sua vez havia servido no exército austríaco. Além de um cortejo fúnebre de uma jovem que havia morrido, provavelmente pelas presas de Carmilla. Diante deste cortejo, Laura começa a cantar louvando a Deus e à alma da moça morta, Carmilla fica incomodada com a situação. Situações estranhas, aparecimento de fantasmas são relatados por camponeses e mortes de jovens começam a ocorrer deste o momento em que Carmilla hospedou-se na casa de Laura.

Tudo isso, começa a causar desconfiança. As atitudes e os hábitos de Carmilla começam a perturbar a mente de Laura. Seus hábitos lhe parecem estranhos para uma jovem. Isto é, Laura descreve Carmilla, como uma jovem linda, mas que aparenta ter saúde frágil. A fragilidade parece decorrer dos hábitos noturnos de Carmilla, momento em que captura suas presas, não permitindo que ela acorde cedo para fazer o desjejum, e quase não se alimenta. Seu alimento é o sangue de suas vítimas, é ele que lhe dá vitalidade e beleza. Portanto, ela se guarda durante boa parte do dia em seu caixão coberto de sangue, onde recupera sua vitalidade e energia. Por isso, às vezes, ela apresenta aparência cansada e frágil, é a sua necessidade e falta do seu alimento revigorante, o sangue.

No decorrer da trama, Laura uma jovem criada sobre os preceitos cristãos, percebe que Carmilla não tem o hábito de rezar, já que pela manhã ela nunca estava acordada e a noite retirava-se antes das preces. Apesar disso, Laura sente-se aliviada em saber que Carmilla era batizada, portanto era cristã. Carmilla diante do contexto social desse período é uma transgressora, suas atitudes afrontam a moral imposta e policiada pela religião. 
Todavia, Carmilla nega o criador, Deus, e coloca a natureza responsável por tudo, “[...] - Criador! Natureza! [...]" (LE FANU, 2010, p. 76), disse Carmilla em um diálogo com o pai de Laura, que expressava preocupação com as mortes misteriosas que haviam assolado a região. Logo, essa negação a Deus expressa a relação que a religião tinha com a mulher dessa época, que era negar e manter sobre total reclusão, a fim de evitar a disseminação da imoralidade, ou seja, a negação de Deus colocando a natureza como responsável pela vida é uma transgressão, uma afronta à moral social da época.

\section{Considerações Finais: d'O Anjo do Lar à Femme Fatale}

Carmilla, assim, representa o desejo, a libertação sexual da mulher vitoriana, desta forma, o medo, o terror da obra não é por ela ser uma assassina e sim por ela despertar a sexualidade dessa mulher reprimida sexualmente. Neste sentido, uma mulher sexualmente ativa afeta a masculinidade do homem, portanto, sua transgressão era romper com os padrões sociais, já que a mulher deveria negar sua sexualidade em prol da sexualidade do homem.

Para penetrar os espaços sociais, usou diferentes nomeações; para Laura e sua família se apresentou com o nome de Carmilla. Em outro momento, coincidentemente, e quando ela ainda estava no castelo e sem saber que a mãe de Laura era descendente da família Karnstein, chegaram alguns quadros antigos, que pertenciam a sua mãe, e seu pai havia mandado restaurar, pois estavam em péssimo estado. Um desses quadros era da condessa chamada Mircalla que impressionou todos pela semelhança com Carmilla. Ela pertence à família Karnstein, que havia morado em um castelo próximo. Seu último nome era Millarca, como se apresenta ao general Spielsdorf.

Esses três anagramas que derivam do nome original, Mircalla, representam as três faces de uma mulher.

De acordo com Campos (2008, p. 82):

Ao pensarmos no número três como um número cabalístico e que, por sua vasta simbologia, nos leva ao reconhecimento de uma manifestação próxima à perfeição da tríade cristã para referir-se a um todo, ou a um único ser dotado de poder e força, as três faces de uma mesma mulher que veste diferentes máscaras sociais: Carmilla, Mircalla e Millarca permitem-nos reconhecer as diferentes manifestações da vampira para infiltrar-se em meio à nova sociedade que ameaça as estruturas mantidas como parâmetro do que é certo.

De acordo com a citação acima, está contida na obra simbologias que adentram a cultura cristã, como é o caso do número três que remete a perfeição e a ordem pai, 
filho e espírito santo. Carmilla, diante de todo preconceito e preocupação com a moral social, ludibria suas vítimas e a sociedade conservadora.

O vampiro é detentor de uma força sobrenatural, assim ocorre com Carmilla, sua imagem doce e meiga, é inteiramente desmascarada diante da sua força brutal. Quando sua verdadeira face é descoberta, Carmilla é atacada em sua tumba pelo general Spielsdorf, “[...] ele golpeou com toda a força, mas ela esquivou do golpe e, ilesa, agarrou-o com aquela mão pequenina. [...]" (LE FANU, 2010, p. 135), sua força fez com que o general deixasse cair o machado e infelizmente Carmilla fugiu. Essa forma brutal também é apresentada pela sua metamorfose. Carmilla tem o poder de se transformar em um animal, ela se transforma em um enorme gato: "[...] No folclore relacionado aos vampiros, especialmente na Grécia, acredita-se que se um gato pular sobre o corpo antes do seu enterro, este transformará em um vampiro. [...]" (LE FANU, 2010, p. 17).

Campos (2008, p. 86) discorre:

Às vezes, o gato preto é visto como um servidor dos infernos e simboliza, então, a obscuridade e a morte; assim, a forma de um gato, que também é atribuída, em muitas culturas à forma da mulher (principalmente por seu caráter dissimulado), é uma perfeita representação do poder de transformação de Carmilla em uma manifestação animal.

A transformação de Carmilla em um animal remete ao seu poder, além disso, o gato representa o obscuro, o oculto, a astúcia, agilidade, desta forma, Le Fanu dá a Carmilla a imagem de um gato como mais uma maneira de distorcer a sua imagem real e expressar o seu poder.

O vampirismo surge com o suicida, uma pessoa que atenta contra sua vida, retorna dos mortos e visita as suas vítimas durante o sono, mordendo-as e após sua morte se transformam em vampiros na sua cova. Foi assim que Carmilla tornou-se vampira e seguiu seu legado eterno em busca de novas vítimas. Tem a capacidade de adentrar e sair de sua cova, sem remexer nenhum tijolo, movimentação de forma assustadora, sem deixar vestígios.

A obra literária Carmilla é uma representação da mulher vitoriana, no que tange sua libertação sexual, da sociedade, da religião e do homem. Quando tratamos de vampiro, este remete a tudo aquilo que é tabu na era vitoriana. A mulher vampira, revive para romper com os grilhões da sociedade conservadora, que atribui à mulher a responsabilidade da família. A homossexualidade de Carmilla corrompe a imagem da mulher mãe, libertando-a desse crivo. Além disso, Carmilla é sensual e sexual, o que tira a mulher da posição de submissa e a coloca como dominadora, o que dentro dos padrões da sociedade é impossível.

A mulher vitoriana é objeto sexual do homem e fantoche da moral social, e Carmilla é a libertação dessa mulher; a partir desse momento ela deseja e sente prazer e está liberta da sociedade opressora, que controla até seus desejos mais íntimos. 
Apesar de Carmilla ter essa representação, a sua morte demostra o fim de tudo aquilo que coloca a sociedade em risco, e a sua morte pelas mãos de um homem de forma extremamente brutal, conforme narra Laura:

[...] uma estaca pontiaguda foi cravada no coração da vampira, que, naquele instante, emitiu um urro lancinante, comparável ao de um mortal em sua agonia derradeira. Em seguida, a cabeça foi decepada, e uma torrente de sangue jorrou do pescoço cortado. $\mathrm{O}$ corpo e a cabeça forma, posteriormente, depositados sobre uma pilha de lenha e reduzidos às cinzas, [...] (LE FANU, 2010, p. 140).

Quando Carmilla é morta todo o perigo foi morto com ela, fazendo com que essa ação torne-se exemplo para outras mulheres subversivas ou que desejam ser, ou seja, essa atitude punitiva, descrita pela narradora, parece alertar outras mulheres para os perigos de agirem de modo subversivo.

A morte de Carmilla pelas mãos do general, com tanta brutalidade, é para assegurar que jamais retornará dos mortos. Além do mais, a obra remete a libertação sexual da mulher vitoriana, onde a vampira é livre, é uma mulher que deixa de ser objeto da sociedade e do homem para buscar seus desejos. Porém, sua morte acaba legitimando ainda mais o poder patriarcal, um vez que a mulher, nessa sociedade vitoriana, não pode abdicar de suas obrigações impostas pela sociedade, mas, sim, que perpetue e continue a aceitar sua posição enquanto mulher submissa, seguidora dos preceitos ditados pela religião, pela sociedade patriarcal e pelo homem, fazendo com que a representação de sua morte dê fim a toda sua luta.

\section{Referências}

BEAUVOIR, Simone de. O segundo sexo: fatos e mitos. 4 ed. Trad. Sérgio Millet. São Paulo: Difusão Européia do Livro (volume I), 1970.

O segundo sexo: a experiência vivida. $2^{\circ}$. Trad. Sérgio Millet. São Paulo: Difusão Européia do Livro (Volume II), 1967.

CAMPOS, Ludmila Rode de. CARMILLA e SABELLA: em busca de uma identidade feminina em Joseph Sheridan Le Fanu e Tanith Lee. 137 f. Dissertação (Mestrado) Curso de Letras, Programa de Pós-Graduação em Letras do Instituto de Biociências, Letras e Ciências Exatas, Universidade Estadual Paulista "Júlio de Mesquita Filho", Campus de São José do Rio Preto. São José dos Campos, 2008.

DEL PRIORE, Mary. História do cotidiano. São Paulo: Contexto, 2001. 
HOBSBAWM, Eric J. A era dos impérios. Rio de Janeiro: Paz e Terra, 1988.

LE FANU, Sheridan. Carmilla, a vampira de Karnstein. São Paulo: HEDRA, 2010.

LIMA, Dante Luiz de. A vida do sangue, o sangue da vida: A influência das "sagradas" escrituras sobre a literatura vampírica. 320 p. Tese (doutorado) - Universidade Federal de Santa Catarina, Centro de Comunicação e Expressão. Programa de Pós Graduação em Literatura, Florianópolis, SC, 2016.

PATMORE, Coventry. The Angel in the House. Harcott: Echo Library, 2006 [1864].

PÉREZ, Francisco Javier Sánchez-Verdejo. Terror y placer: hacia una (re)construcción cultural del mito del vampiro y su proyección sobre lo femenino en la literatura escrita en lengua inglesa. $1264 \mathrm{f}$. Tese (Doutorado) - Curso de Filosofia, Universidad de Castilla-la Mancha, Cuenca, 2011.

PERROT, Michelle. Minha história das mulheres. 2.ed. São Paulo: Contexto, 2016.

. As mulheres ou os silêncios da história. Bauru. Edusc, 2005.

. Os excluídos da história: operários, mulheres e prisioneiros. Rio de janeiro: Paz

e Terra, 1988.

STRACHEY, GilesLytton. Rainha Vitoria. Rio de Janeiro: Bestbolso, 2015.

Recebido: 07.11.2018

Aceito: 07.06.2018 